\title{
Analisis Determinan Minat Beli Beras Organik oleh lbu Rumah Tangga di Desa
}

\author{
Eny Safitri \\ Institut Agama Islam Negeri Surakarta \\ Enysafitri1102@gmail.com
}

Septin Puji Astuti

Institut Agama Islam Negeri Surakarta

septin.astuti@iain-suraarta.ac.id, septin.astuti@gmail.com

\section{Suggested Citation:}

\begin{tabular}{l} 
Chen, M. (2007). Consumer attitudes and purchase intentions in relation to organic foods in Taiwan: Moderating \\
\hline effects of food-related personality traits. Food Quality and Preference, 18, 1008-1021. \\
\hline http:/ldoi org/10.1016/.foodgual 2007.04 .004
\end{tabular}
http://doi.org/10.1016/i.foodqual.2007.04.004

Abstract:

This study intends to investigate the determinant factor of the intention to purchase organic rice by housewife in Sambi Village. Five variables are applied to identify the influence to intention to purchase organic rice. Those variables are subjective norm, health awareness, knowledge, perceived price, and attitude as the mediation variable. This study involved 100 housewives from Sambi Village. The sample was taken in cluster and systematic sampling to ensure probabilistic requirements of path and regression analysis is implemented to data analysis. This study confirmed the Theory of Planned Behavior that attitude is mediated by subjective norm to influence intention to purchase. Additionally, price influenced significantly to intention to purchase organic rice. However, the influence of health awareness and knowledge to intention to purchase organic rice is unable to be proven in this study.

Keywords intention to purchase; organic rice; price; subjective norm; theory of planned behaviour

Abstrak:

Penelitian ini bermaksud untuk mengetahui faktor-faktor yang berpengaruh terhadap minat membeli beras organik. Ada lima variabel yang akan diuji untuk melihat keterkaitannya dengan minat beli beras organik. Variabel-variabel tersebut adalah norma subyektif, kesadaran kesehatan, pengetahuan, persepsi terhadap harga, dan sikap sebagai mediasi antara variabelvariabel tersebut. Data yang digunakan dalam penelitian ini adalah sebanyak 100 responden yang mereka adalah ibu rumah tangga di Desa Sambi. Sample diambil secara klaster per Rukun Tetangga (RT) dan kemudian dilakukan secara sistematik untuk menjaga data agar memenuhi sifat probabilistik yang menjadi dasar dari path analisis dengan analisis regresi yang akan digunakan untuk analisis data. Hasil dari penelitian ini mengonfirmasi Theory of Planned Behaviour bahwa norma subyektif dengan dimediasi oleh sikap mempengaruhi seseorang untuk membeli beras organik. Selain itu, harga juga berpengaruh kepada ibu rumah tangga untuk memiliki minat beli beras organik. Sementara pengaruh kesadaran akan kesehatan dan pengetahuan terhadap minat beli beras organik, dalam penelitian ini tidak mampu dibuktikan secara nyata.

Kata kunci beras organik; harga; norma subyektif; minat beli; theory of planned behaviour

JEL Classification: M30, M31 


\section{Pendahuluan}

Demi terjaminnya kelangsungan hidup, manusia harus memenuhi kebutuhan hidupnya. Salah satunya adalah makan. Namun, semakin berkembangnya pengetahuan manusia, beredar makanan yang mengandung zat-zat berbahaya yang dapat mempengaruhi kesehatan manusia. Sosialisasi yang dilakukan oleh pemerintah tentang pentingnya makanan sehat bagi keluarga yang dilakukan melalui media diharapkan dapat meningkatkan kesadaran masyarakat akan pentingnya mengonsumsi makanan yang sehat. Selain dari pemerintah, munculnya produk-produk makanan yang sehat yang terbuat dan diproses secara organik juga semakin menyadarkan masyarakat untuk mengonsumsi makanan sehat melalui produk-produk makanan organik.

Kesadaran masyarakat akan efek berbahaya dari bahan kimia yang terkandung dalam makanan meningkat sehingga mendorong mereka mengonsumsi makanan organik (Basha et al., 2015). Masalah kesehatan ini yang menjadi faktor pendorong konsumen membeli produk makanan organik (Paul \& Rana, 2012). Kesadaran konsumen terhadap makanan sehat organik ikut menggeser pandangan produsen yang awalnya memproduksi pangan secara konvensional kini berganti menjadi sistem pertanian organik (Asif et al., 2018). Oleh karenanya, untuk meningkatkan penjualan produknya, produsen harus mengikuti trend permintaan konsumen akan makanan yang sehat. Kesadaran akan kesehatan mengacu pada pemikiran konsumen pada perkembangan lingkungan (Kim \& Chung, 2011) dan kesehatan diri (Jayanti \& Burns, 1998).

Umumnya, harga makanan organik dibuat lebih tinggi dibandingkan produk maknan konvensional karena memiliki keunggulan dalam masalah kesehatan dan lingkungan (Paul \& Rana, 2012; Selfa et al., 2008). Namun, pembeli produk organik pada umumnya berasal dari kalangan orang yang memiliki pengetahuan dan mereka bahkan mengabaikan harga (Sheng-Hsiung Chang Chin-Wen Chang, 2017). Mereka ini adalah kelompok yang bersifat refleksi (Torjusen et al., 2001). Mendapatkan keuntungan dalam hal kesehatan dan lingkungan yang menjadi kelebihan dari produk organik membuat mereka bersedia membayar lebih.

Di samping harga, masyarakat Indonesia sebagai bagian dalam negara dengan kebudayaan yang beraneka ragam dalam hal konsumsi pun masih menganut norma-norma seperti norma subjektif. Dalam theory of planned behaviour, norma subyektif dengan dimediasi oleh sikap memberi kontribusi dalam memotivasi konsumen untuk membeli. Selain itu, telah dibuktikan dalam beberapa penelitian bahwa sikap juga mampu memoderasi norma subyektif dalam menentukan minat konsumen untuk membeli (Chen, 2007). Ini berarti, sikap dapat bertindak sebagai pengantar norma subyektif supaya mendorong orang untuk berminat konsumsi, juga sekaligus mampu menguatkan norma subyektif untuk mendorong orang memiliki minat konsumsi.

Indonesia adalah negara yang mendapat julukan sebagai negara agraris karena sebagian besar penduduk Indonesia bekerja di bidang pertanian atau bercocok tanam. Kesadaran maupun pengetahuan makan makanan sehat apalagi kalangan ibu rumah tangga selaku pemerhati asupan makanan keluarga sewajarnya sudah tinggi. Namun, pada praktiknya belum sepenuhnya terdapat konsistensi antara pengetahuan yang dimiliki dengan minat pembelian atau perilaku konsumsi nyata dari konsumen. Pengambil keputusan dalam pembelian bahan pangan untuk konsumsi sehari-sehari didominasi oleh perempuan khususnya dari kalangan ibu rumah tangga yang memiliki gaya hidup berorientasi pada kesehatan keluarga (Novandari, 2011).

Penelitian ini dimaksudkan untuk melihat minat beli beras organik pada masyarakat di Desa Sambi, Kecamatan Sambi, Kabupaten Boyolali. Wilayah ini dipilih karena di wilayah ini terdapat banyak petani yang memproduksi padi secara organik. Di level kabupaten, kelompok produsen padi organik diwadahi dalam Asosiasi Petani Organik Boyolali (APPOLI). Selain masyarakatnya banyak yang berprofesi sebagai petani organik, pemilihan lokasi ini juga didukung oleh adanya pemasar beras organik. Hal ini terlihat dengan keberadaan koperasi Sahabat Sejahtera di Desa Sambi, Kecamatan Sambi, dalam menjalankan fungsi pemasaran APPOLI di wilayah tersebut. Dengan adanya pemasar berarti terdapat pembeli padi organik di Desa Sambi.

\section{Literatur Review}

\section{Makanan organik}

Makanan organik adalah makanan yang menghindari perlakuan kimia dalam masa produksi, pengolahan, maupun penyimpanannya (Basha et al., 2015). Sementara, padi organik adalah padi yang disahkan oleh suatu badan independen, ditanam dan diolah menurut standar yang telah ditetapkan (Syam, 2008). Secara umum, definisi organik terpenuhi apabila memenuhi berbagai persyaratan yaitu tidak menggunakan pestisida dan pupuk 
kimia dalam budi daya dan pengolahannya, kesuburan tanah dipelihara melalui proses alami, tanaman dirotasikan untuk menghindari penanaman komoditas yang sama secara terus-menerus, dan pemanfaatan bahan non kimia.

Tidak semua makanan yang terlihat segar itu termasuk atau bisa dikatakan makanan sehat dan organik. Seperti yang dijelaskan sebelumnya, untuk dapat dikatakan sebagai makanan organik, sebuah produk harus memenuhi beberapa kualifikasi yang telah ditentukan. Seperti halnya dalam cara produksi atau budidayanya yang alami tidak memakai bahan-bahan kimia yang dapat berpengaruh pada kesehatan manusia atau menghindari penggunaan obat-obatan buatan, menghindari organisme dari rekayasa genetika, dan/atau pewarna serta perasa buatan sehingga lebih aman dikonsumsi dan baik untuk kesehatan (Limantara, 2017).

\section{Perilaku konsumsi dalam Theory of Planned Behaviour}

Perilaku merupakan salah satu faktor utama dan sangat penting bagi strategi pemasaran, karena hanya melalui perilaku, penjualan dapat dilakukan oleh pemasar dengan melakukan analisis, memahami, dan mempengaruhi perilaku konsumen yang pada akhirnya akan mendatangkan keuntungan yang diharapkan. Perilaku (behavior) mengacu kepada aksi fisik konsumen secara langsung yang dapat diamati dan diukur oleh pihak lainnya (Peter \& Olson, 2013).

Dalam membantu para pemasar menemukan cara terbaik dalam melakukan serangkaian strategi, telah dilakukan berbagai macam penelitian, diantara yang sering ditemukan dalam penelitian-penelitian sebelumnya terkait perilaku konsumen ialah Theory of Planned Behavior (TPB). Theory of Planned Behavior (TPB) didasarkan pada kepentingan diri sendiri dan rasional berdasarkan pilihan adalah model utama dalam menentukan sikap yang dirasakan untuk melakukan perilaku tertentu. Dalam penelitian ini menggunakan Theory of Planned Behavior (TPB) sebagai landasan teori utama dalam membuat model penelitian.

Sikap sendiri adalah hasil dari pembelajaran atau pengalaman dan persepsi seseorang (Schiffman \& Kanuk, 2007). Pengalaman dan persepsi konsumen akan membentuk sebuah kecenderungan tertentu dalam berperilaku secara konsisten ketika konsumen hendak merespon suatu stimulan. Sikap adalah pernyataanpernyataan evaluatif mengenai objek, orang, atau peristiwa (Robbin \& Judge, 2015). Sikap dapat diartikan sebagai kecenderungan yang dipelajari untuk memberikan respon atau menerima rangsangan terhadap objek secara konsisten baik dalam rasa suka maupun tidak suka (Putra et al., 2016). Sikap pada makanan organik yaitu perasaan atau evaluasi umum tentang membeli makanan organik berdasarkan keyakinan membeli makanan organik (Wijaya, 2014).

Norma subyektif merupakan salah satu faktor yang signifikan mempengaruhi niat konsumen untuk membeli produk tertentu (Asif et al., 2018). Orang cenderung mengikuti kelompok referensi, pemimpin yang pada gilirannya mempengaruhi kelompok terhadap perilaku dan tindakan tertentu. Kelompok rujukan atau grup referensi melibatkan satu atau lebih orang yang dijadikan sebagai dasar pembanding atau titik referensi dalam membentuk tanggapan afeksi dan kognisi serta menyatakan perilaku seseorang (Setiadi, 2003).

Niat beli pada produk pangan organik adalah keinginan atau ekspresi niat seorang konsumen untuk berkomitmen melakukan pembelian produk pangan organik (Chan \& Lau, 2000; Novianto \& Setyowati, 2009). Untuk mendukung keputusan pembelian, konsumen atau masyarakat akan memilah-milah keinginan dan kebutuhannya ketika dihadapkan dengan suatu keputusan sehingga membutuhkan persepsi yang tepat. Dalam pemasaran, seorang pemasar perlu mengetahui persepsi seseorang atau lebih tepatnya keinginan yang diharapkan yang ada dalam fikiran konsumen yang akan berimbas kepada niat beli atau tindakan mereka selanjutnya (Schiffman \& Kanuk, 2007).

\section{Kesadaran kesehatan, pengetahuan, dan harga serta perannya dalam perilaku konsumsi makanan organik}

Kesadaran kesehatan mengacu pada sejauh mana masalah kesehatan diintegrasikan atau diartikan dalam aktivitas atau kegiatan sehari-hari seseorang (Jayanti \& Burns, 1998). Dalam health belief model yang dibangun oleh Yazdanpanah et al. (2015) membuktikan bahwa 42\% variabel kesadaran kesehatan memberi kontribusi terhadap minat konsumen membeli produk organik. Dalam penelitian lain, kesadaran kesehatan pada makanan organik adalah pendorong orang bersikap terhadap produk organik (Thøgersen \& Zhou, 2012). 
Pengetahuan konsumen adalah semua informasi yang dimiliki oleh konsumen mengenai berbagai macam produk dan jasa, serta pengetahuan lainnya terkait dengan produk dan jasa tersebut (Dwiastuti et al., 2012). Pengetahuan akan makanan merupakan faktor penting yang dapat mempengaruhi perilaku konsumen dimana pengetahuan merupakan pembelajaran kognitif (Sapp, 1991). Pengetahuan organik didefinisikan sebagai kemampuan konsumen dalam mengidentifikasi sejumlah konsep yang berkaitan dengan produk organik melalui informasi yang dimiliki konsumen (Chan \& Lau, 2000). Guna mengembangkan strategi pemasaran secara efektif, pemasar harus memahami berbagai jenis tingkatan atau jenis pengetahuan konsumen. Seberapa jauh mereka memahami akan produk atau bahkan sekedar tahu akan produk itu (Peter \& Olson, 2013). Pengetahuan yang tidak cukup juga menentukan keputusan konsumen untuk membeli produk organik (Zepeda \& Deal, 2009). Bahkan, pengetahuan dan informasi yang baik akan produk organik dianggap mampu mendorong orang membeli produk organik dibandingkan dengan label organik yang disematkan dalam produk organik (Foster, 2005).

Harga dapat menjadi diferensiasi suatu produk yang dapat menarik minat beli konsumen (Irawan et al., 1996). Jadi, harga dapat menjadi salah satu pertimbangan yang amat penting bagi konsumen guna memunculkan minat dan perilaku selanjutnya. Makanan organik seringnya dijual dengan harga yang lebih tinggi yang tentu saja akan berpengaruh pada minat belinya. Semakin tinggi harganya, semakin kecil peluang konsumen memilihnya karena harga lebih rendah bisa jadi keunggulan suatu produk. Terutama di negara-negara berkembang yang ekonomi masyarakatnya tidak tinggi, harga menjadi faktor untuk dipertimbangkan dalam pembelian.

\section{Kerangka konseptual penelitian}

Penelitian perilaku konsumsi produk organik dilakukan oleh beberapa peneliti. Kim dan Chung (2011) mendeteksi hubungan antara variabel-variabel dalam TPB seperti sikap, perceived behavioral control, norma subyektif ditambah dengan pengalaman terdahulu dan nilai konsumen yang didalamnya terdiri kesadaran kesehatan, lingkungan, dan penampilan. Sementara Chen (2007) juga melakukan hal yang hampir sama dengan Kim dan Chung (2011) namun dengan studi kasus di Taiwan. Hanya saja penelitiannya norma subyektif tidak mempengaruhi orang untuk membeli produk organik. Sebelumnya, Arvola et al. (2008) menerapkan TPB dengan sampel penelitian dilakukan di Italia, Finlandia, dan Inggris dengan pengaruh dominan yang berbeda-beda. Penelitian ini diperkuat oleh penelitian Thøgersen dan Zhou (2012) yang menghasilkan norma subyektif yang memiliki pengaruh kecil terhadap minat beli produk organik. Sementara itu, Yazdanpanah et al. (2015) membuktikan bahwa masalah kesehatan menjadi pemicu kuat orang membeli produk organik.

Singh dan Verma (2017) membuktikan bahwa kesadaran kesehatan, pengetahuan, norma subjektif, harga, dan ketersediaan menjadi pendorong sikap konsumen organik dalam membeli. Sikap dan kesadaran kesehatan dalam penelitian Asif et al. (2018) merupakan variabel terbaik yang mempengaruhi niat beli makanan organik. Sementara studi Yadav dan Pathak (2016) di negara berkembang membuktikan bahwa sikap moral dan kesadaran kesehatan positif mempengaruhi niat beli konsumen pada makanan organik.

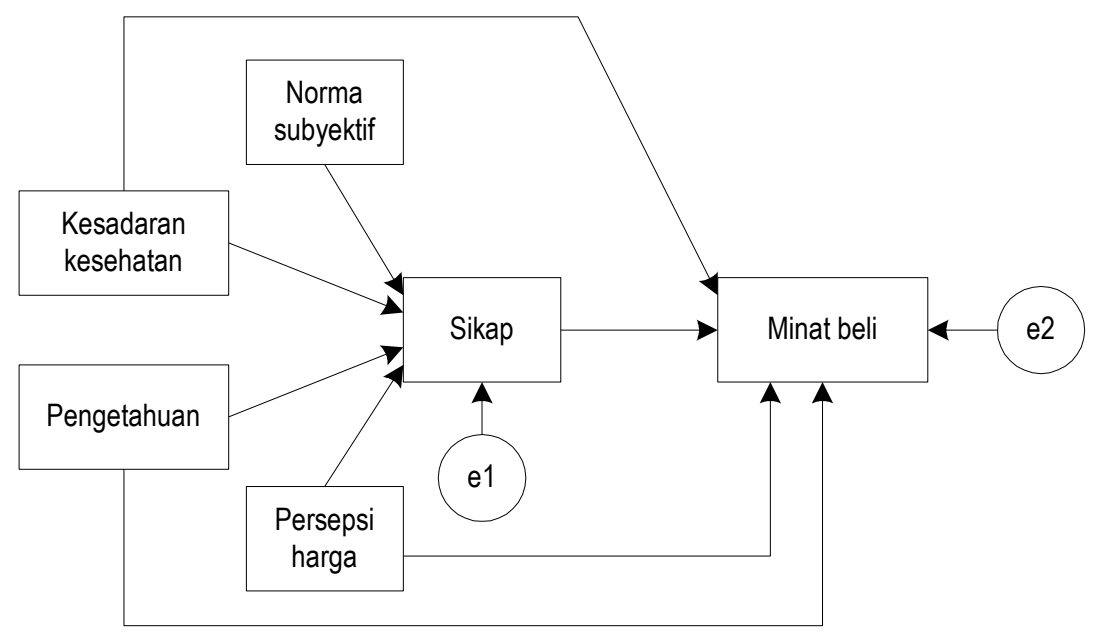

Gambar. 1.Model penelitian 
Variabel-variabel tersebut dalam penelitian ini dihubungkan dengan model struktural seperti ditunjukkan pada Gambar 1. Model tersebut kemudian diujikan dengan menggunakan data yang ada. Dari model tersebut, hipotesis yang akan diujikan dalam penelitian ini ada 2 yaitu Model 1: $f(m)=f\left(x_{1}, x_{2}, x_{3}, x_{1}\right)$ dengan hipotesis adalah, $\mathrm{H}_{0}$ : Variabel norma subyektif, kesadaran kesehatan, pengetahuan makanan organik, dan persepsi harga berpengaruh terhadap sikap. Sementara Model 2: $f(y)=f\left(x_{1}, x_{2}, x_{3}, x_{1}, m\right)$ hipotesisnya adalah $\mathrm{H}_{0}$ : Variabel norma subyektif, kesadaran kesehatan, pengetahuan makanan organik, persepsi harga, dan sikap berpengaruh terhadap minat beli beras organik.

\section{Research Method}

\section{Rancangan pengambilan data}

Penelitian ini dilakukan pada ibu rumah tangga di Desa Sambi, Kecamatan Sambi, Kabupaten Boyolali yang populasinya adalah 1397 ibu rumah tangga. Sasaran penelitian adalah mereka yang belum atau sudah mengonsumsi beras organik. Maka, jumlah populasi ibu rumah tangga di Untuk menjaga agar pengambilan sample mengikuti kaidah probability sampling dan menjaga keterwakilan sample, maka pada penelitian ini digunakan teknik pengambilan cluster sampling dan systematic sampling. Cluster sampling adalah dengan membagi kelompok sample dalam Rukun Tetangga (RT). Di Desa Sambi terdapat 23 RT. Dalam penelitian ini direncanakan akan diambil 100 responden. Sehingga, masing-masing RT akan diambil 100/23 $=4,35 \approx 4$ sampai 5 sample. Setelah itu, baru di setiap RT dilakukan teknik sistematic sampling dengan mengambil sample pada rumah tangga dengan kelipatan 13 (1397 populasi/100 sample). Jumlah data yang diambil adalah 100 responden. Seperti dalam analisis regresi, dalam path analysis banyaknya observasi lebih besar dari banyaknya parameter. Norman dan Streiner (2008) menghiting jumlah pengamatan dengan rumus $(\mathrm{k}(\mathrm{k}+1)) / 2$. Analisis data dilakukan dengan menggunakan path analysis untuk menguji model usulan pada Gambar 1. Hal ini karena path analysis tidak untuk membangun model, namun untuk menguji model apa yang sesuai dengan data (Streiner, 2005). Asumsi yang mendasari analisis data juga diukur dalam penelitian ini. Tujuannya adalah untuk melihat ketepatan model dan hasil estimasi parameternya.

\section{Hasil Penelitian}

\section{Profil responden dan analisis deskriptif}

Responden pada penelitian ini adalah ibu rumah tangga di Desa Sambi, Kecamatan Sambi, Kabupaten Boyolali. Profil dari responden ditunjukkan pada Tabel 1. Responden dalam penelitian ini didominasi oleh mereka yang berusia antara 31 hingga 50 tahun. Lebih dari 50 persen responden dalam penelitian ini tingkat pendidikannya adalah lulusan Sekolah Menengah Atas. Tidak ada satupun di antara mereka yang melanjutkan ke perguruan tinggi. Ini menggambarkan bahwa mayoritas ibu rumah tangga di Desa Sambi adalah bukan dari kelompok wanita yang berpendidikan tinggi.

Tabel 1. Profil responden

\begin{tabular}{|l|l|l|l|}
\hline \multicolumn{1}{|c|}{ Variabel } & Persentase $(\%)$ & Variabel & Persentase (\%) \\
\hline Usia & & Pendidikan terakhir & \\
\hline $10-30$ tahun & 22 & Sekolah Dasar (SD) & 11 \\
\hline $31-40$ tahun & 29 & Sekolah Menengah Pertama (SMP) & 29 \\
\hline $41-50$ tahun & 30 & Sekolah Menengah Atas (SMA) & 60 \\
\hline $51-60$ tahun & 15 & Diploma/Sarjana & 0 \\
\hline Lebih dari 60 tahun & 4 & & \\
\hline
\end{tabular}

Sumber : Data diolah (2020)

Sementara, analisis deskriptif dari variabel-variabel yang digunakan dalam penelitian ini ditunjukkan pada Tabel 2. Dari tabel tersebut nampak jelas bahwa dengan menggunakan skala 1 sampai 5 , pengetahuan akan 
makanan organik pada ibu rumah tangga di Desa Sambi bernilai tinggi $(3,77)$. Ini karena banyak dari mereka yang pekerjaannya atau pekerjaan suaminya adalah sebagai petani organik. Sementara kesadaran akan kesehatan dari makanan organik juga bernilai cukup tinggi, yaitu 4,33. Hanya saja, meski kesadaran kesehatan produk organik tinggi, minat beli beras organik mereka tidak setinggi kesadaran kesehatannya $(3,51)$.

Tabel 2 juga menunjukkan korelasi antar variabel. Nilai korelasi ini digunakan untuk memprediksi adanya hubungan antar variabel yang nanti akan diuji lebih mendalam. Dari uji korelasi, nampak jelas bahwa norma subyektif memiliki hubungan korelasi lebih dari 0,2 dengan variabel sikap dan minat beli beras organik. Harga dan sikap juga memiliki hubungan dengan minat beli beras organik. Sementara, variabel kesadaran kesehatan dan pengetahuan memiliki korelasi yang lebih kecil pada sikap dan juga pada minat beli beras organik. Hasil analisis korelasi inilah yang menjadi dasar dalam melakukan analisis selanjutnya.

Tabel 2. Analisis deskriptif dan korelasi

\begin{tabular}{|c|c|c|c|c|c|c|c|c|}
\hline \multirow{2}{*}{ Variabel } & \multirow{2}{*}{$\begin{array}{c}\text { Rata- } \\
\text { rata total } \\
(\mu)\end{array}$} & \multirow{2}{*}{$\begin{array}{l}\text { Rata- } \\
\text { rata }\end{array}$} & \multirow{2}{*}{$\begin{array}{l}\text { Standard } \\
\text { Deviasi } \\
(\sigma)\end{array}$} & \multicolumn{5}{|c|}{ Korelasi $(\rho)$} \\
\hline & & & & $x_{2}$ & $x_{3}$ & $x_{4}$ & $m$ & $y$ \\
\hline Norma subyektif $\left(x_{1}\right)$ & 17,70 & 3,54 & 3,57 & $-0,028$ & 0,192 & 0,092 & 0,263 & 0,269 \\
\hline Kesadaran kesehatan $\left(x_{2}\right)$ & 25,80 & 4,30 & 2,14 & 1 & 0,095 & $-0,142$ & 0,188 & $-0,127$ \\
\hline Pengetahuan makanan organik $\left(x_{3}\right)$ & 18,86 & 3,77 & 1,74 & & 1 & $-0,064$ & 0,124 & $-0,050$ \\
\hline Harga $\left(\mathrm{x}_{4}\right)$ & 9,95 & 3,32 & 1,53 & & & 1 & $-0,040$ & 0,249 \\
\hline Sikap $(m)$ & 13,30 & 2,66 & 1,23 & & & & 1 & 0,309 \\
\hline Minat beli $(y)$ & 14,04 & 3,51 & 0,25 & & & & & 1 \\
\hline
\end{tabular}

Sumber : Data diolah (2020)

\section{Uji model dengan Analisis Path dan Analisis Regresi}

Instrumen yang telah digunakan diuji validitas dan reliabilitasnya hasilnya ditunjukkan pada Tabel 3. Nampak jelas bahwa item yang digunakan sudah valid dan reliabel. Ini artinya item yang digunakan sudah konsisten dan mampu mewakili variabel-variabel tersebut. Selanjutnya dilakukan analisis untuk menguji model.

Tabel 3. Uji validitas dan reliabilitas instrumen

\begin{tabular}{|c|c|c|c|c|c|}
\hline \multirow{2}{*}{ Variabel } & \multirow{2}{*}{ Item } & \multicolumn{2}{|c|}{ Uji validitas } & \multicolumn{2}{|c|}{ Uji reliabilitas } \\
\hline & & $\overline{\text { Korelasi }(\rho)}$ & Keputusan & Alpha-Crobach & Keputusan \\
\hline \multirow[t]{5}{*}{ Norma subyektif } & NS1 & 0,805 & Valid & 0,928 & Reliabel \\
\hline & NS2 & 0,881 & Valid & & \\
\hline & NS3 & 0,898 & Valid & & \\
\hline & NS4 & 0,916 & Valid & & \\
\hline & NS5 & 0,891 & Valid & & \\
\hline \multirow[t]{6}{*}{ Kesadaran kesehatan } & KK1 & 0,580 & Valid & 0,685 & Reliabel \\
\hline & KK2 & 0,667 & Valid & & \\
\hline & KK3 & 0,592 & Valid & & \\
\hline & KK4 & 0,647 & Valid & & \\
\hline & KK5 & 0,644 & Valid & & \\
\hline & KK6 & 0,613 & Valid & & \\
\hline \multirow[t]{5}{*}{ Pengetahuan pangan organik } & P1 & 0,606 & Valid & 0,8337 & Reliabel \\
\hline & P2 & 0,777 & Valid & & \\
\hline & P3 & 0,866 & Valid & & \\
\hline & P4 & 0,873 & Valid & & \\
\hline & P5 & 0,726 & Valid & & \\
\hline \multirow[t]{3}{*}{ Persepsi harga } & $\mathrm{H} 1$ & 0,766 & Valid & 0,877 & Reliabel \\
\hline & $\mathrm{H} 2$ & 0,954 & Valid & & \\
\hline & $\mathrm{H} 3$ & 0,956 & Valid & & \\
\hline \multirow[t]{3}{*}{ Sikap } & S1 & 0,819 & Valid & 0,725 & Reliabel \\
\hline & S2 & 0,882 & Valid & & \\
\hline & S3 & 0,700 & Valid & & \\
\hline
\end{tabular}




\begin{tabular}{|c|c|c|c|c|c|}
\hline \multirow{2}{*}{ Variabel } & \multirow{2}{*}{ Item } & \multicolumn{2}{|c|}{ Uji validitas } & \multicolumn{2}{|c|}{ Uji reliabilitas } \\
\hline & & Korelasi $(\rho)$ & Keputusan & Alpha-Crobach & Keputusan \\
\hline Minat beli & M1 & 0,797 & Valid & 0,894 & Reliabel \\
\hline & $\mathrm{M} 2$ & 0,908 & Valid & & \\
\hline & M3 & 0,891 & Valid & & \\
\hline & M4 & 0,888 & Valid & & \\
\hline
\end{tabular}

Sumber : Data diolah (2020)

Dari analisis data dalam Tabel 4, ada dua model yang diuji dengan hipotesis seperti yag dtelah dipaparkan pada Bab II. Variabel-variabel yang signifikan pada level $\alpha=5 \%$ untuk Model 1 adalah norma subyektif $\left(x_{1}\right)$ dan kesadaran kesehatan $\left(\mathrm{x}_{2}\right)$. Sementara hubungan antara variabel pengetahuan dan harga dengan sikap tidak dapat didukung oleh data yang cukup. Sedangkan pada Model 2, variabel yang sigifikan pada level $\alpha=5 \%$ yaitu norma subyektif $\left(\mathrm{x}_{1}\right)$, persepsi harga $\left(\mathrm{x}_{4}\right)$, dan variabel sikap $(\mathrm{m})$. Menariknya, pada model ini, variabel harga menjadi signifikan, sedangkan variabel kesadaran kesehatan tidak signifikan berada dalam model. Namun demikian, variabel norma subyektf signifikan pada kedua model tersebut.

Tabel 4. Hasil analisis dengan analisis regresi

\begin{tabular}{|c|c|c|c|c|}
\hline Model & Koefisien & $p$-value & $\mathrm{R} 2$ & R2-adj \\
\hline \multicolumn{5}{|c|}{ Model 1: $f(m)=f\left(x_{1}, x_{2}, x_{3}, x_{4}\right)$} \\
\hline Konstanta $\left(\beta_{1}\right)$ & 14,71 & 0,000 & 11,79 & 8,07 \\
\hline$\beta_{1}$ & 0,085 & $0,014^{* *}$ & & \\
\hline$\beta_{2}$ & $-0,116$ & $0,041^{* *}$ & & \\
\hline$\beta_{3}$ & 0,040 & 0.366 & & \\
\hline$\beta_{4}$ & $-0,069$ & 0,382 & & \\
\hline \multicolumn{5}{|c|}{ Model 2: $\mathrm{f}(\mathrm{y})=\mathrm{f}\left(\mathrm{x}_{1}, \mathrm{x}_{2}, \mathrm{x}_{3}, \mathrm{x}_{4}, \mathrm{~m}\right)$} \\
\hline Konstanta $\left(\beta_{1}\right)$ & 3,26 & 0,487 & 20,37 & 16,13 \\
\hline$\beta_{1}$ & 0,134 & $0,048^{* *}$ & & \\
\hline$\beta_{2}$ & $-0,032$ & 0,773 & & \\
\hline$\beta_{3}$ & $-0,093$ & 0,276 & & \\
\hline$\beta_{4}$ & 0,372 & $0,016^{\star \star}$ & & \\
\hline$\beta_{m}$ & 0,548 & $0,006^{\star \star *}$ & & \\
\hline
\end{tabular}

Sumber : Data diolah (2020)

Keterangan: tanda * signifikan pada $\alpha=10 \%$, tanda ${ }^{* *}$ signifikan pada $\alpha=5 \%$, dan tanda ${ }^{* * *}$ signifikan pada $\alpha=1 \%$.

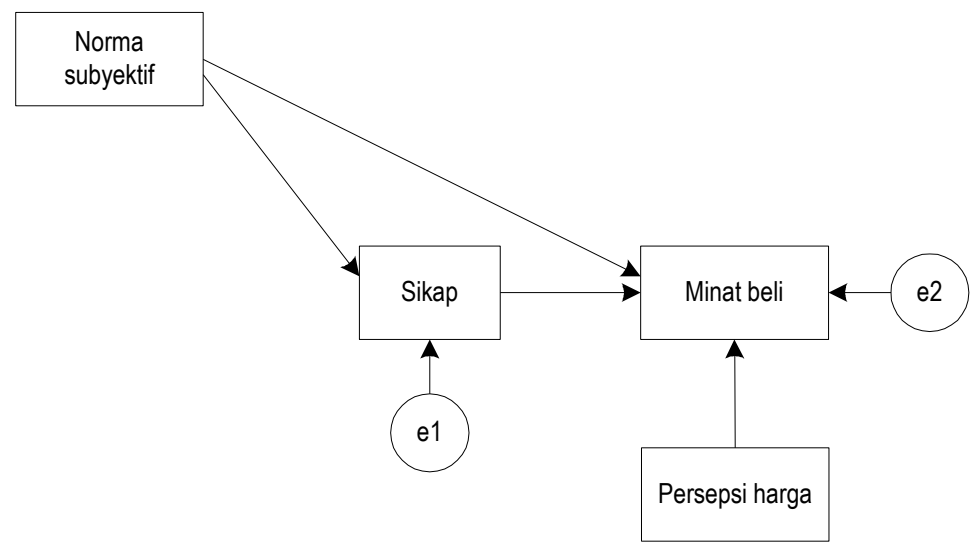

Gambar 2. Model modifikasi

Oleh karena dalam kedua model ini tidak semua variabel signifikan, maka perlu melakukan modifikasi model dengan tanpa menyertakan variabel-variabel yang tidak signifikan dalam model (Schumacker \& Lomax, 2004). Modifikasi model dilakukan untuk menghasilkan estimasi parameter yang sesuai. Penggunaan estimasi parameter yang tidak signifikan hanya akan menghasilkan estimasi yang tidak tepat. Hasil modifikasi model 
ditunjukkan pada Gambar 2. Dalam model modifikasi ini, sikap hanya dipengaruhi oleh norma subyektif, sementara minat beli dipengaruhi oleh norma subyektif, sikap dan persepsi harga. Untuk itu, dua model ini diuji kesesuainnya dengan data yang ada.

Model 4 pada Tabel 5 adalah model untuk menentukan path dari penentu minat beli beras organik yang dibentuk oleh tiga variabel independen yaitu norma subyektif, harga, dan sikap yaitu $\left(\mathrm{f}(\mathrm{y})=\mathrm{f}\left(\mathrm{x}_{1}, \mathrm{x}_{4}, \mathrm{~m}\right)\right.$ ). Sementara, Model 5 membentuk path dari penentu sikap yang dalam penelitian ini ditentukan oleh norma subyektif $\left(\mathrm{f}(\mathrm{y})=\mathrm{f}\left(\mathrm{x}_{1}, \mathrm{x}_{4}, \mathrm{~m}\right)\right)$. Model 6,7 , dan 8 hanya model tambahan untuk menguji adanya pengaruh variabel secara individual. Model-model tersebut kemudian diuji parameternya dan selanjutnya dilakukan uji normality test residualnya, multikolinearitas, heteroskedastisitas dan autokorelasi antar variabelnya. Uji-uji ini dilakukan karena ketidaksesuaian hasil dengan asumsi dasar analisis regresi akan berpengaruh pada estimasi parameter modelnya (Schumacker \& Lomax, 2004). Normality test dari residual menggunakan KolmogorovSmirnov test, uji heteroscedasticity menggunakan White test (Gujarati, 2003), uji . Hasil uji asumsi model ditunjukkan pada Tabel 5.

Tabel 5. Hasil analysis dari model yang sudah dimodifikasi

\begin{tabular}{|c|c|c|c|c|c|c|c|c|}
\hline Model & Koefisien & $p$-value & $R^{2}$ & $R^{2}$-adj & $\begin{array}{l}\text { Normality } \\
\text { test (K-S) }\end{array}$ & $\begin{array}{c}\text { White test } \\
\text { heteroskedasticity } \\
\left(\chi^{2}\right)\end{array}$ & $\begin{array}{l}\text { Multiko- } \\
\text { linearity } \\
\text { (VIF) }\end{array}$ & $\begin{array}{l}\text { DW-test } \\
\text { (d) }\end{array}$ \\
\hline \multicolumn{2}{|c|}{$\begin{array}{l}\text { Model 4: } \\
\mathrm{f}(\mathrm{y})=\mathrm{f}\left(\mathrm{x}_{1}, \mathrm{x}_{4}, \mathrm{~m}\right)\end{array}$} & & 19.21 & 16.68 & 0,145 & 1086 & & $2.207^{*}$ \\
\hline Konstanta $\left(\beta_{0}\right)$ & 0,78 & 0,789 & & & & & & \\
\hline$\beta_{1}$ & 0,120 & $0,070^{*}$ & & & & & 1,09 & \\
\hline$\beta_{4}$ & 0,544 & $0,005^{\star * *}$ & & & & & 1,08 & \\
\hline$\beta_{\mathrm{m}}$ & 0,391 & $0,010^{* *}$ & & & & & 1,01 & \\
\hline \multicolumn{2}{|c|}{ Model 5: $\mathrm{f}(\mathrm{m})=\mathrm{f}\left(\mathrm{x}_{1}\right)$} & & 6,91 & 5,96 & $0,027^{*}$ & 156 & & $2,194^{*}$ \\
\hline Konstanta $\left(\beta_{0}\right)$ & 7,410 & $0,000^{\star * *}$ & & & & & & \\
\hline$\beta_{1}$ & 0,090 & $0,008^{* * *}$ & & & & & 1,00 & \\
\hline \multicolumn{2}{|c|}{ Model 6: $\mathrm{f}(\mathrm{y})=\mathrm{f}\left(\mathrm{x}_{1}\right)$} & & 7,25 & 6,64 & $<0.010^{*}$ & 505 & & $1,926^{*}$ \\
\hline Konstanta $\left(\beta_{0}\right)$ & 10,770 & $0,000^{* * *}$ & & & & & & \\
\hline$\beta_{1}$ & 0,185 & $0,007^{* * *}$ & & & & & 1,00 & \\
\hline \multicolumn{2}{|c|}{ Model 7: $\mathrm{f}(\mathrm{y})=\mathrm{f}(\mathrm{m})$} & & 9,52 & 8,60 & $<0,010^{*}$ & 691 & & $1,872^{*}$ \\
\hline Konstanta $\left(\beta_{0}\right)$ & 5,850 & $0,025^{\star * *}$ & & & & & & \\
\hline$\beta_{\mathrm{m}}$ & 0,616 & $0,002^{* * *}$ & & & & & 1,00 & \\
\hline \multicolumn{2}{|c|}{ Model 8: $\mathrm{f}(\mathrm{y})=\mathrm{f}\left(\mathrm{x}_{4}\right)$} & & 6,20 & 5,25 & $<0,010^{*}$ & 238 & & $2,048^{*}$ \\
\hline Konstanta $\left(\beta_{0}\right)$ & 10,060 & $0,000^{\star * *}$ & & & & & & \\
\hline$\beta_{\mathrm{m}}$ & 0,400 & $0,012^{\star * *}$ & & & & & 1,00 & \\
\hline & & & & & & & & \\
\hline
\end{tabular}

Sumber : Data diolah (2020)

Berdasarkan lima model pada Tabel 5, parameter variabel norma subyektif pada Model 4 tidak signifikan pada $\alpha=5 \%$. Sementara pada Model 5 nampak jelas bahwa varibel norma subyektif memberi secara statistik signifkan mempengaruhi sikap ibu rumah tangga. Juga, pada 7 terdapat bukti bahwa secara signifikan variabel sikap ibu rumah tangga di Desa Sambi berpengaruh terhadap minat beli beras organik. Sementara, dalam Model 6 terlihat nyata bahwa variabel norma subyektif berpengaruh terhadap minat beli beras organik. Sedangkan Model 8 nampak nyata bahwa harga secara statistik berpengaruh signifikan terhadap minat beli beras organik. Di antara Model 6, 7, dan 8, yang menghasilkan R2 paling besar adalah Model 7.

Berdasarkan Model 4 dan 6 dilakukan perhitungan indirect effect dari norma subyektif ke minat beli. Rumus indirect effect yang digunakan mengikuti Fairchild et al. (2009) dan Heus (2012). Sehingga, indirect effect norma subyektif ke minat beli adalah sebagai berikut:

Norma subyektif $\rightarrow$ sikap $\rightarrow$ minat beli $=0,09 \times 0,391=0,0352$

Norma subyektif $\rightarrow$ minat beli $\quad=0,120$ 
Berdasarkan nilai tersebut, indirect effect norma subyektif menuju minat beli adalah 0,0351 $+0,120=0,155$. Nilai ini lebih besar daripada direct effect norma subyektif menuju minat beli yang bernilai 0,120 . Besarnya nilai indirect effect antara norma subyektif dan minat beli dibanding direct effect-nya menunjukkan bahwa penambahan variabel sikap sebagai variabel mediasi mampu menguatkan hubungan antar keduanya. Dari hasil ini, hubungan antara norma subyektif dalam mendorong seseorang memiliki niat beli beras organik dikuatkan oleh adanya variabel sikap.

Sebelumnya, dengan menggunakan Moderated Regression Analysis Chen (2007) membuktikan bahwa norma subyektif dengan dimoderasi oleh sikap mampu memberi kontribusi pada perilaku konsumsi makanan organik. Pada penelitian ini juga akan diujikan model moderasi sikap terhadap norma subyektif yang dimodifikasi dari Model pada Gambar 2. Sehingga modelnya seperti dalam Gambar 3.

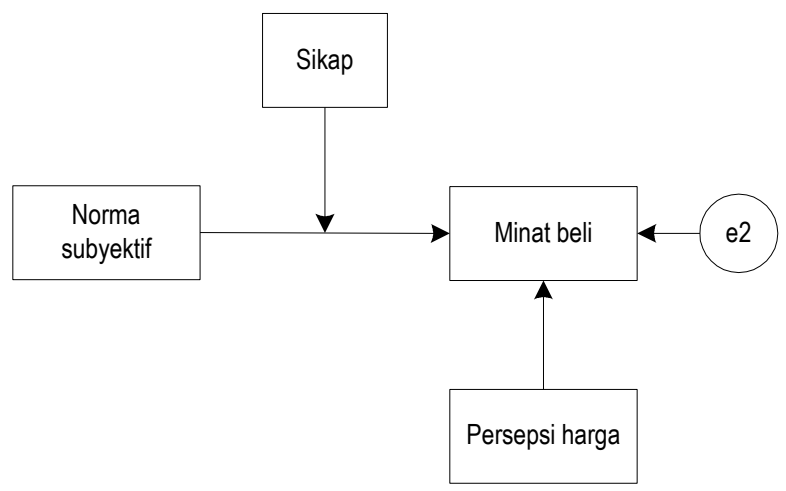

Gambar 3. Model modifikasi dengan variabel sikap sebagai moderator atas norma subyektif

Tabel 5. Hasil analysis dari model modifikasi dengan variabel sikap sebagai moderasi

\begin{tabular}{|c|c|c|c|c|c|c|c|c|}
\hline Model & Koefisien & p-value & $\mathrm{R} 2$ & R2-adj & $\begin{array}{l}\text { Normality } \\
\text { test }\end{array}$ & $\begin{array}{l}\text { White test } \\
\text { heteros- } \\
\text { kedasticity } \\
\left(\chi^{2}\right)\end{array}$ & $\begin{array}{l}\text { Multiko- } \\
\text { linearity } \\
\text { (VIF) }\end{array}$ & $\begin{array}{l}\text { DW-test } \\
\text { (d) }\end{array}$ \\
\hline \multicolumn{3}{|c|}{ Model 9: $f(y)=f\left(x_{4}, x_{1} * m\right)$} & 15,71 & 13,97 & 0,043 & 1089 & & $1,9775^{\star}$ \\
\hline Konstanta $\left(\beta_{0}\right)$ & $-24,300$ & $0,000^{\star *}$ & & & & & & \\
\hline$\beta_{4}$ & 0,418 & $0,016^{* * *}$ & & & & & 1,00 & \\
\hline$\beta_{1} * \beta_{\mathrm{m}}$ & $-0,1131$ & $0,001^{* *}$ & & & & & 1,00 & \\
\hline
\end{tabular}

Sumber : Data diolah (2020)

Dari Model 9 dalam Tabel 5, dimana sikap adalah moderasi dari norma subyektif, sangat jelas bahwa model sudah signifikan secara statistika. Namun dari uji asumsi, hanya uji distribusi normal pada residual yang masih belum memenuhi syarat. Jika syarat itu diabaikan, sikap sebagai moderasi dari norma subyektif beserta persepsi harga dalam membentuk perilaku pembelian pada beras organik dianggap cukup mampu mewakili data dalam penelitian ini. Jika dibandingkan dengan Model 4, asumsi yang mendasari model sudah terpenuhi. Hanya saja, variabel norma subyektif tidak signifikan mempengaruhi minat beli beras organik apabila variabel norma subyektif dihubungkan secara bersamaan dengan sikap dan harga. Ketidak-signifikanan parameter norma subyektif bisa diakibatkan oleh adanya kolinearitas antar variabel independen. Dilihat dari korelasi pada Tabel 2, Nampak jelas bahwa korelasi antara sikap dan norma subyektif nilainya hampir sama dengan korelasi antara norma subyektif terhadap minat beli. Dalam analisis regresi tidak boleh terjadi multikolinearity yang diindikasikan dengan adanya korelasi antar variabel independen (x). Hal ini karena akan menghasilkan estimasi parameter yang tidak tepat (Gujarati, 2003). Sementara, ketidak-normalan residual Model 9 bisa terjadi karena data yang terbentuk pada penelitian ini adalah jumlahan dari skala Likert yang sifatnya diskrit dan berskala ordinal. 


\section{Pembahasan}

Penelitian ini membuktikan bahwa pengetahuan responden akan produk organik tidak memberi dampak pada minat pembelian beras organik. Seringkali konsumen membeli produk organik tanpa memiliki pengetahuan apapun tentang produk tersebut. Dalam penelitian ini yang respondennya adalah ibu rumah tangga yang tinggal di desa yang pendidikannya di bawah Sekolah Menengah Atas, pengetahuan bisa jadi tidak memberi kontribusi dalam perilaku konsumsi mereka. Menilik pendapat Moser (2016) yang mengatakan bahwa kepercayaan akan produk lebih berperan dalam mendorong seseorang melakukan perilaku konsumsi produk organik dibandingkan pengetahuannya bisa jadi berlaku pada data dalam penelitian ini.

Dalam penelitian ini, norma subyektif yang dikuatkan oleh sikap memberi peran dalam menentukan ibu rumah tangga untuk membeli beras organik. Ini sesuai dengan theory of planned behavior di mana norma subyektif mempengaruhi sikap dan sikap tersebut dapat menjadi mediator dari norma subyektif untuk berminat membeli beras organik. Namun jika bersama dengan harga dan sikap, norma subyektif tidak memberi pengaruh signifikan terhadap minat beli. Dalam penelitian ini, variabel norma subyektif tidak signifikaan saat menjadi variabel independen bersama degan sikap dan harga itu karena sikap dan norma subyektif memiliki hubungan (korelasi) yang sama besarnya hubungannya dengan minat beli. Yazdanpanah dan Forouzani (2015) juga membuktikan dalam penelitiannya bahwa norma subyektif tidak berpengaruh terhadap minat beli produk organik, akan tetapi sikap, identitas diri, dan norma moral yang berpengaruh terhadap minat beli beras organik. Dalam dalam studi minat beli makanan organik yang dilakukan oleh Arvola et al. (2008) di Inggris dan Itali minat beli cenderung besar dipengaruhi oleh sikap, sementara di Finlandia norma subyektif lebih berpengaruh daripada sikap. Sementara Tarkiainen \& Sundqvist (2005) mengatakan bahwa norma subyektif berpengaruh secara tidak langsung ke minat beli. Dalam penelitian ini, sikap juga bisa bertindak sebagai moderator. Ini artinya sikap menjadi penguat norma subyektif dalam mempengaruhi minat beli beras organik yang hal ini dibuktikan dari uji Model 9. Ini seperti hasil riset yag dilakukan oleh Chen (2007).

Norma subyektif, yang merupakan perwujudan dari hubungan sosial manusia dengan orang lainnya, berperan sangat penting dalam membentuk sikap seseorang. Sikap inilah yang berperan dalam mengambil keputusan untuk bertindak. Apalagi di kehidupan di desa, dimana hubungan sosial antar masyarakat jauh lebih kuat, peran norma subyektif menjadi signifikan. Pembentukan sikap yang terjadi akibat pengaruh lingkungan masyarakat ini kemudian diwujudkan dalam perilaku. Termasuk di dalamnya adalah perilaku pembelian.

Selain norma subyektif, peran persepsi harga dalam penelitian ini cukup signifikan. Harga beras organik pada umumnya lebih tinggi dari beras biasa. Ibu-ibu di Desa Sambi memiliki minat beli dengan rata-rata minat berkisar antara $14,04 / 4=3,51$. Dengan nilai tersebut artinya ibu rumah tangga di Desa Sambi cenderung memiliki minat beli beras organik yang berkisar antara ragu-ragu dan berminat membeli. Berdasarkan hasil ini, diduga, harga yang lebih tinggi dari beras organik inilah mempengaruhi minat mereka. Hasil penelitian yang dilakukan oleh Zepeda dan Deal (2009) menunjukkan bahwa yang membuat konsumen tidak mau membeli produk organik karena harga yang tinggi. Produk organik dianggap sebagai produk mewah karena harganya lebih tinggi (Fifita et al., 2019).

Tentu ini berbeda dengan karakter konsumen produk organik yang tidak memperdulikan harga. Meski harganya mahal bukan menjadi penentu perilaku konsumen, namun lebih pada pengetahuan mereka akan produk organik (Sheng-Hsiung Chang Chin-Wen Chang, 2017). Pengetahuan berpengaruh pada sikap yang kemudian mempengaruhi perilaku membeli produk organik (Pieniak et al., 2010). Pengetahuan dapat diperoleh melalui pendidikan. Studi dari Paul dan Rana (2012) juga membuktikan bahwa konsumen dengan pendidikan tinggi memiliki kecenderungan membeli produk organik. Sementara, dalam penelitian ini yang dilakukan pada ibu rumah tangga di desa yang mana pendidikan mereka tidak ada satupun yang di Perguruan Tinggi memiliki demografi yang berbeda. Faktor pengetahuan dan kesadaran kesehatan bukanlan faktor dominan dalam mengonsumsinya beras organik. Namun, harga menjadi faktor penting karena bagi kalangan masyarakat desa yang ada umumnya adalah kalangan masyarakat ekonomi menengah ke bawah, harga mahal itu berhubungan dengan kemampuan beli.

\section{Kesimpulan}

Variabel-variabel yang diusulkan dalam model di penelitian ini tidak semuanya mampu didukung oleh data yang kuat. Beberapa variabel yang tidak memberi dampak signifikan pada minat beli beras organik seperti kesadaran kesehatan dan pengetahuan. Hubungan sosial yang kuat di desa, baik hubungan antar keluarga, teman, dan tetangga merupakan bagian dari norma subyektif lebih banyak mempengaruhi perilaku konsumsi mereka dalam memberi beras organik. Dalam hal ini, adanya 'role model' yang berada di sekitar mereka 
berperan kuat dalam tindakan mereka menentukan keputusan mengonsumsi beras organik. Sementara harga dalam penelitian ini masih menjadi faktor penentu minat beli beras organik. Penelitian ini yang dilakukan pada ibu-ibu rumah tangga dan tinggal di desa, memberikan implikasi bahwa untuk memasarkan beras organik kepada mereka harus memperhatikan peran hubungan sosial dengan orang di sekitar. Selain itu, harga adalah penting dibandingkan dengan pemberian pengetahuan dan menyadarkan akan pentingnya kesehatan pangan.

\section{Daftar Pustaka}

Arvola, A., Vassallo, M., Dean, M., Lampila, P., Saba, A., Lähteenmäki, L., \& Shepherd, R. (2008). Predicting intentions to purchase organic food: The role of affective and moral attitudes in the Theory of Planned Behaviour. Appetite, 50(2-3), 443-454. http://doi.org/10.1016/j.appet.2007.09.010

Asif, M., Xuhui, W., Nasiri, A., \& Ayyub, S. (2018). Determinant factors influencing organic food purchase intention and the moderating role of awareness: A comparative analysis. Food Quality and Preference, 63, 144-150.

Basha, M. B., Mason, C., Shamsudin, M. F., Hussain, H. I., \& Salem, M. A. (2015). Consumers Attitude Toward Organic Food. Journal of Procedia Economics and Finance, 31(444), 452.

Chan, R. Y. K., \& Lau, L. B. Y. (2000). Antecedents of Green Purchases: A Survey in China. Journal of Consumer Marketing, 17(4), 338-357.

Chen, M. (2007). Consumer attitudes and purchase intentions in relation to organic foods in Taiwan : Moderating effects of food-related personality traits. Food Quality and Preference, 18, 1008-1021. http://doi.org/10.1016/j.foodqual.2007.04.004

Dwiastuti, R., Shinta, A., \& Isaskar, R. (2012). Ilmu Perilaku Konsumen. Malang: Universitas Brawijaya (UB) Press.

Effendi, S., \& Tukiran. (2012). Metode Penelitian Survey (Edisi Revi). Jakarta: LP3ES.

Fairchild, A. J., MacKinnon, D. P., Taborga, M. P., \& Taylor, A. B. (2009). R2 effect-size measures for mediation analysis. Behavior Research Methods, 41(2), 486-498. http://doi.org/10.3758/BRM.41.2.486

Fifita, I. M. E., Seo, Y., Ko, E., Conroy, D., \& Hong, D. (2019). Fashioning organics: Wellbeing, sustainability, and status consumption practices. Journal of Business Research, (January), 1-8. http://doi.org/10.1016/j.jbusres.2019.01.005

Foster, S. P. C. (2005). Exploring the gap between attitudes and behaviour buy organic food. British Food Journal, 107(8), 606-625. http://doi.org/10.1108/00070700510611002

Gujarati, D. N. (2003). Basic Econometrics (Fourth Edi). New York: McGraw-Hill.

Heus, P. De. (2012). R squared effect-size measures and overlap between direct and indirect effect in mediation analysis. Behavior Research, 44, 213-221. http://doi.org/10.3758/s13428-011-0141-5

Irawan, Wijaya, F., \& Sudjono. (1996). Pemasaran (Prinsip dan Kasus) (Ed. Ke-2). Yogyakarta: BPFEYogyakarta.

Jayanti, R. K., \& Burns, A. C. (1998). The antecedents of preventive health care behavior: An empirical study. Journal of the Academy of Marketing Science, 26(1), 6-15.

Kim, H. Y., \& Chung, J. (2011). Consumer purchase intention for organic personal care products. Journal of Consumer Marketing, 28(1), 40-47. http://doi.org/10.1108/07363761111101930

Limantara, Y. D. P. (2017). Pengaruh Customer Perception Terhadap Minat Beli Konsumen Melalui Multiatribute Attitude Model Pada Produk Makanan Organik. Jurnal Manajemen Pemasaran, 11(2), 69-78.

Moser, A. K. (2016). Buying organic - decision making heuristics and empirical evidence from Germany. Journal of Consumer Marketing, 33(7), 552-561.

Norman, G. R., \& Streiner, D. L. (2008). Path Analysis and Structural Equation Modeling. In Biostatistics: the Bare Essentials (pp. 211-228). Hamilton: B.C. Decker Inc.

Novandari, W. (2011). Analisis Motif Pembelian dan Profil Perilaku "Green Product Customer" (Studi Pada konsumen Produk Pangan Organik di Purwokerto). JEBA, 13(1), 17-23.

Novianto, F. W., \& Setyowati, E. (2009). Analisis Produksi Padi Organik di Kabupaten Sragen Tahun 2008. Jurnal Ekonomi Pembangunan, 10(2), 267-288.

Paul, J., \& Rana, J. (2012). Consumer behavior and purchase intention for organic food. Journal of Consumer Marketing, 29(6), 412-422. http://doi.org/10.1108/07363761211259223

Peter, J. P., \& Olson, J. C. (2013). Perilaku Konsumen dan Strategi Pemasaran. Jakarta: Salemba Empat. 
Pieniak, Z., Aertsens, J., \& Verbeke, W. (2010). Subjective and objective knowledge as determinants of organic vegetables consumption. Food Quality and Preference, 21(6), 581-588. http://doi.org/10.1016/j.foodqual.2010.03.004

Putra, K. T. E., Sukaatmadja, P. G., \& Yasa, N. K. (2016). Perilaku Konsumen Mengkonsumsi Beras Organik di Kota Denpasar Berdasar Theory of Planned Behavior. Jurnal Ekonomi \& Bisnis Universitas Udayana, 8(3), 2609-2638.

Robbin, S. P., \& Judge, T. A. (2015). Perilaku Organisasi. Jakarta: Salemba Empat.

Sapp, S. G. (1991). Impact of Nutritional Knowledge Within an Expanded Rational Expectation: Model of Beef Consumption. J. Nutr. Educ Behav, 23(5), 214-222.

Schiffman, L. G., \& Kanuk, L. L. (2007). Customer Behavior (Ninth Edition). New York: Pearson Prentice Hall.

Schumacker, R. E., \& Lomax, R. G. (2004). A Beginner's Guide to Structural Equation Modelling. New Jersey: Lawrence Erlabaum Associates.

Selfa, T., Jussaume, R. A., \& Winter, M. (2008). Envisioning agricultural sustainability from field to plate: Comparing producer and consumer attitudes and practices toward "environmentally friendly" food and farming in Washington State, USA. Journal of Rural Studies, 24, 262-276. http://doi.org/10.1016/j.jrurstud.2007.09.001

Sheng-Hsiung Chang Chin-Wen Chang. (2017). Tie strength, green expertise, and interpersonal influences on organic food purchase in an emerging market. British Food Journal, 119(2).

Singh, A., \& Verma, P. (2017). Factors influencing Indian consumers' actual buying behaviour towards organic food products. Journal of cleaner production. Journal of Cleaner Production, 167, 473-483.

Streiner, D. L. (2005). Finding Our Way: An Introduction to Path Analysis. The Canadian Journal of Psychiatry, 50(2), 115-122.

Syam, M. (2008). Padi organik dan tuntutan peningkatan produksi beras. Iptek Tanaman Pangan, 3(1), 1-8.

Tarkiainen, A., \& Sundqvist, S. (2005). Subjective norms, attitudes and intentions of Finnish consumers in buying organic food. British Food Journal, 107, 808-822. http://doi.org/10.1108/00070700510629760

Thøgersen, J., \& Zhou, Y. (2012). Chinese consumers' adoption of a "green" innovation - The case of organic food. Journal of Marketing Management, 28(3-4), 313-333. http://doi.org/10.1080/0267257X.2012.658834

Torjusen, H., Lieblein, G., Wandel, M., \& Francis, C. A. (2001). Food system orientation and quality perception among consumers and producers of organic food in Hedmark County, Norway. Food Quality and Preference, 12, 207-216.

Wijaya, T. (2014). Nilai dan Pengetahuan Sebagai Prediktor Intensi Beli Makanan Organik. Jurnal Manajemen Dan Kewirausahaan, 16(1), 69-82.

Yadav, R., \& Pathak, G. S. (2016). Intention to purchase organic food among young consumers: Evidences from a developing nation. Appetite, 96, 122-128.

Yazdanpanah, M., \& Forouzani, M. (2015). Application of the Theory of Planned Behaviour to predict Iranian students â€ $€^{\mathrm{TM}}$ intention to purchase organic food. Journal of Cleaner Production, 107, 342-352. http://doi.org/10.1016/j.jclepro.2015.02.071

Yazdanpanah, M., Forouzani, M., \& Hojjati, M. (2015). Willingness of Iranian young adults to eat organic foods : Application of the Health Belief Model. Food Quality and Preference, 41, 75-83. http://doi.org/10.1016/j.foodqual.2014.11.012

Zepeda, L., \& Deal, D. (2009). Organic and local food consumer behaviour : International JOurnal of Cosumer Studies, 33, 697-705. http://doi.org/10.1111/j.1470-6431.2009.00814.x 